\title{
INFLUENCE OF PRODUCT QUALITY, PRICE, AND QUALITY OF SERVICE TO CUSTOMER SATISFACTION (STUDY ON RESTO SOLARIA MALL LIPPO CIKARANG)
}

\author{
Erdi Erdi');Dadang Heri Kusumah²); Sumardjono, Sumardjono³); Dimas Ari \\ Darmantyo ${ }^{4)}$
}

\author{
${ }^{1,2)}$ Departement of Management Pelita Bangsa University, Bekasi. Indonesia \\ ${ }^{2.3)^{*}}$ Departement of Management Universitas Binaniaga Indonesia, Bogor. Indonesia \\ 1)abu.zulqarnaen@gmail.com; ${ }^{2)}$ dadangherikusumah3@pelitabangsa.ac.id; ${ }^{3}$ sdjonref18@gmail.com; \\ 4)*dim.askurei@gmail.com
}

* Corresponding author

Received: June 1, 2021; Accepted: June 29, 2021; Published: June 30, 2021

To cite this article: Erdi,E.,Kusumah, D.H.,Sumardjono,S.,\& Darmantyo,D.A. Influence of product quality, price, and quality of service to customer satisfaction (study on Resto Solaria Mall Lippo Cikarang), The Management Journal of BINANIAGA, 6(1), 95-102. doi: 10.33062/mib.v6i1.443

Abstract. This research aims to test some of the influence of product quality on customer satisfaction, test some of the influence of price on customer satisfaction, and partly test the influence of service quality on customer satisfaction, as well as conducted at SOLARIA Resto Mall Lippo Cikarang. The sampling method used is non-probability sampling i.e. quota sampling. The sample of this study was 100 respondents who had visited THE SOLARIA Mall Lippo Cikarang restaurant, and those respondents distributed an online questionnaire through the google form. This research is based on multiple linear regression analysis, with the help of SPSS statistical procedures, to test the validity and reliability of research tools in the form of partial tests (t-tests) and simultaneous tests (F-tests), classic assumption tests and hypothesis tests.hypothesis test ( $F$ test), the results obtained are the quality of the product has a positive and significant effect on consumer satisfaction. There is a positive and significant influence of price on consumer satisfaction. There is a positive and significant influence of service quality on customer satisfaction. There is an influence of product quality, price, and quality of service simultaneously to customer satisfaction Resto SOLARIA Mall Lippo Cikarang.This suggests that all hypotheses in this study were accepted.

Keywords: Product Quality, Price, Quality of Service, and Customer Satisfaction

Background

\section{INTRODUCTION}

Increasing the business actors who set up a business based on culinary, be it in the form of traditional restaurants, fine restaurants and cafes. At this time restaurants and cafes have become an integral part of human life. Therefore the existence of restaurants and cafes has become a necessity. This is related to the higher level of mobility of the community and dense work activities and resulted in more and more people spending their time outside the home so that people are looking for something practical to meet their daily needs, namely by visiting restaurants, restaurants and cafes.

The restaurant is one of the places that providing food requests. As a result of lifestyle changes, restaurants are growing rapidly, and today's lifestyle requires individuals to do a lot of activities outside the home. This is why people don't have enough time to cook at home today. This is what drives the development of restaurants as providers of food needs outside the home. Restaurants not only provide food, but

Erdi,Dadang Heri Kusumah, Sumardjono, and Dimas Ari Darmantyo. Influence of product quality, price, and quality of service to customer satisfaction (study on Resto Solaria Mall Lippo Cikarang) 
more developed towards finding a comfortable food atmosphere, different tastes and even home entertainment venues. This is the difference between restaurants and other food providers such as Resto Solaria. Resto Solaria need to anticipate stiff competition. One of the efforts that can be done by entrepreneurs in the field of culinary or catering is to provide and improve customer satisfaction. Customer satisfaction is considered as a determinant of attitude after making a purchase and reflects as a positive or negative result, which comes from the personal experience felt by the consumer. Consumer satisfaction or consumet satisfaction has meaning as a function of how appropriate the expectations of product buyers with the performance that buyers think of the product. Here are the sales data of Resto SOLARIA Mall Lippo Cikarang in 2019 as follows:

Table 1

Sales Data for Resto SOLARIA Mall Lippo Cikarang

\begin{tabular}{llr}
\hline \multicolumn{1}{c}{ MONTH } & REVENUES & \multicolumn{1}{c}{ REMARKS } \\
\hline January & IDR123.000.000 & \\
\hline February & IDR114.000.000 & $(-)$ IDR9.000.000 \\
\hline March & IDR98.000.000 & $(-)$ IDR16.000.000 \\
\hline April & IDR107.000.000 & $(+)$ IDR9.000.000 \\
\hline May & IDR108.000.000 & $(+)$ IDR1.000.000 \\
\hline June & IDR137.000.000 & $(+)$ IDR29.000.000 \\
\hline July & IDR134.000.000 & $(-)$ IDR3.000.000 \\
\hline August & IDR109.000.000 & $(-)$ IDR25.000.000 \\
\hline September & IDR153.000.000 & $(+)$ IDR44.000.000 \\
\hline October & IDR108.000.000 & $(-)$ IDR45.000.000 \\
\hline November & IDR189.000.000 & $(+)$ IDR81.000.000 \\
\hline December & IDR179.000.000 & $(-)$ IDR10.000.000 \\
\hline \multicolumn{2}{r}{ Source: Resto Solari Mall }
\end{tabular}

Source: Resto Solaria Mall Lippo Cikarang

The table above indicates that the total revenue of Resto SOLARIA Mall Lippo Cikarang fluctuates every month. The highest amount of revenue in 2019 in November amounted to IDR189,000,000, an increase in revenue of IDR81,000,000 up from the previous month's revenue of IDR108,000,000,000, and there were some decreases in revenue experienced by Resto SOLARIA Mall Lippo Cikarang which occurred in February, March, July, August, and October. The largest decrease in 2019 was in October, amounting to IDR45,000,000 down from the previous month's revenue of IDR153,000,000. From the data above there are some decreases in sales of Resto SOLARIA Mall Lippo Cikarang due to decreased customer satisfaction.

Erdi,Dadang Heri Kusumah, Sumardjono, and Dimas Ari Darmantyo. Influence of product quality, price, and quality of service to customer satisfaction (study on Resto Solaria Mall Lippo 


\section{REVIEW OF LITERATURE}

According to Kotler and Keller (2013, 138-139), satisfaction is a person's feeling of pleasure or disappointment after comparing the perceived performance of a product to its expectations. If the product performance is lower than expected, the consumer will feel dissatisfied. Conversely, if performance meets or even exceeds expectations, consumers will be satisfied. Satisfied consumers typically maintain longer loyalty to products, buy back when companies developed and innovated products, and talk to others about the company's products and kind words. According to Tjiptono (2014; 368-369), among the different ways of measuring consumer satisfaction, there are four core concepts of objects to be measured:

1. Overall Customer Satisfaction;

2. Confirmation of Expectation;

3. Repurchase of Intent; and

4. Willingness of Recommended.

According to Tjiptono in Afnina, 2018, product quality is an effort made by manufacturers in an effort to meet or even exceed consumer expectations; quality includes products produced, services, people, processes, as well as the environment. According to Tjiptono $(2019 ; 76-77)$ there are several dimensions or factors of product quality used to evaluate customer satisfaction or dissatisfaction. The dimensions are as follows:

1. Performance;

2. Features;

3. Reliability;

4. Literature;

5. Aesthetics; and

6. Perceived quality.

Kotler \&Armstrong in Sumardjono \& Ardila(2018), price is a certain amount of value charged on a product or service provided by a consumer to obtain and benefit from using a product or service. Stanton $(2018 ; 308)$ mentions the following indicators:

1. Affordability of prices;

2. Price conformity with product quality;

3. Price competitiveness; and

4. Suitability of prices with benefits.

Lovelock, Wirtz, and Mussry (2010:154) suggest that the quality of service is something that can continue to meet or exceed the expectations of customers or consumers. In fact, the definition of service quality only focuses on the efforts to fulfill the needs and desires of consumers in accordance with their expectations.

Parasuraman in Tjiptono, 2014; 282 identifies five dimensions that can be used to evaluate the quality of service as follows:

1. Direct evidence;

2. Reliability;

3. Responsiveness;

4. Warranties; and

5. Empathy.

Erdi,Dadang Heri Kusumah, Sumardjono, and Dimas Ari Darmantyo. Influence of product quality, price, and quality of service to customer satisfaction (study on Resto Solaria Mall Lippo Cikarang) 


\section{RESEARCH METHODOLOGY}

This research uses quantitative research approach. The research design in this research is the associative research design, which is the research design used to test certain hypotheses and use the t-test to test the relationship between the variables studied to determine the partial and simultaneous influence of free variables.

The population in the research is not known for certain or is said to be infinite population, the sampling techniques using non probability sampling techniques with quota sampling approach. The number of respondents in this research amounted to 100 consumer respondents from Resto SOLARIA Mall Lippo Cikarang. Data collection is obtained through the dissemination of online questionnaires via google form. Each statement item uses a measurement scale called the Likert Scale. The data analysis test in this study consists of Instrument Test consisting of Validity Test and Reliability Test. Classic Assumption Test, Hypothesis Test consisting of Partial Test (t Test) and Simultaneous Test (F Test).

\section{RESULTS AND DISCUSSION}

Table 2

Validity Test Results

\begin{tabular}{lll}
\multicolumn{1}{c}{ Variables } & Results & Remarks \\
\hline Product Quality & $r_{\text {count }}>r_{\text {table }}$ & Valid \\
\hline Price & $r_{\text {count }}>r_{\text {table }}$ & Valid \\
\hline Quality of Service & $r_{\text {count }}>r_{\text {table }}$ & Valid \\
\hline Consumer Satisfaction & $r_{\text {count }}>r_{\text {table }}$ & Valid \\
\hline
\end{tabular}

Based on the data above can be known that all data is declared valid, so that it can conduct the next test, namely, Reliability Test.

Table 3

Reliability Test

\begin{tabular}{lccl}
\hline Variables & Item & $\begin{array}{c}\text { Cronbach } \\
\text { Alpha }\end{array}$ & Results \\
\hline Product Quality & 20 & $0.917>0.6$ & Reliable \\
\hline Price & 10 & $0.837>0.6$ & Reliable \\
\hline Quality of Service & 15 & $0.905>0.6$ & Reliable \\
\hline Consumer Satisfaction & 15 & $0.909>0.6$ & Reliable \\
\hline
\end{tabular}

Based on the data above can be known that all data is declared reliable, so that it can conduct further tests, namely Classic Assumption Test.

Table 4

Classical Assumption Test Results

\begin{tabular}{ll}
\hline \multicolumn{1}{c}{ Classical Assumption Test } & \multicolumn{1}{c}{ Remarks } \\
\hline Normality Test & Data is normally distributed \\
\hline Heteroscedasticity Test & No symptoms of heterokedastisity \\
\hline Multicollinearity Test & $\begin{array}{l}\text { No symptoms of multicolinearity between } \\
\text { independent variables }\end{array}$ \\
\hline
\end{tabular}

Based on the data in the table above can be known that all classic assumption tests have been conducted, so that it can be continued to the Hypothesis Test.

Erdi,Dadang Heri Kusumah, Sumardjono, and Dimas Ari Darmantyo. Influence of product quality, price, and quality of service to customer satisfaction (study on Resto Solaria Mall Lippo

Cikarang) 
Table 5

Hypothesis Test (t Test) and (F Test)

\begin{tabular}{|c|c|c|}
\hline Hypothesis & Results & Remarks \\
\hline \multirow[t]{2}{*}{$\mathrm{H} 1=\mathrm{X} 1>\mathrm{Y}$} & $T_{\text {count }}>t_{\text {table }}$ & $\begin{array}{c}\text { BelDReciably positive and partially } \\
\text { sianificant }\end{array}$ \\
\hline & $<0.05$ & \\
\hline \multirow[t]{2}{*}{$\mathrm{H} 2=\mathrm{X} 2 \rightarrow \mathrm{Y}$} & $T_{\text {count }}>$ ttable & $\begin{array}{l}\text { BelDReciably positive and partially } \\
\text { significant }\end{array}$ \\
\hline & $<0.05$ & \\
\hline \multirow[t]{2}{*}{$\mathrm{H} 3=\mathrm{X} 3 \rightarrow \mathrm{Y}$} & $T_{\text {count }}>$ table & $\begin{array}{l}\text { BelDReciably positive and partially } \\
\text { significant }\end{array}$ \\
\hline & $<0.05$ & \\
\hline \multirow[t]{2}{*}{$\begin{array}{l}\mathrm{H} 4 \\
\mathrm{X} 1, \mathrm{X} 2, \mathrm{X} 3 \rightarrow \mathrm{Y}\end{array}$} & $\mathrm{F}_{\text {count }}>\mathrm{F}_{\text {table }}$ & $\begin{array}{l}\text { BelDReciably positive and significant } \\
\text { simultaneously }\end{array}$ \\
\hline & $<0.05$ & \\
\hline
\end{tabular}

\section{Discussion}

1. Influence of Product Quality on Consumer Satisfaction at Resto SOLARIA Mall Lippo Cikarang

This research also provides evidence that the first hypothesis received is the quality of belDReciably positive and significant products to the satisfaction of consumers who have visited and visited the Resto SOLARIA Mall Lippo Cikarang. Based on the partial calculation of the influence of product quality on consumer satisfaction obtained a regression coefficient value of 0.597 . At the level of significance $5 \%$ obtained $t$ count of 9,430 , greater than the table $t$ value of 1,984 . The resulting significance value of 0.000 means less than 0.05 . Therefore, it can be said that the variable quality of BelDReciably products is significant to consumer satisfaction. Because the coefficient of regression value is positive, it can be concluded that the variable quality of BelDReciably products is positive and significant to the customer satisfaction of Resto SOLARIA Mall Lippo Cikarang, so the first hypothesis is accepted. The higher or better the quality of products at Resto SOLARIA Mall Lippo Cikarang, the customer satisfaction of Resto SOLARIA Mall Lippo Cikarang will increase.

The results of this research are in line with research conducted by Nel Arianty (2015) and Afnina and Yulia Hastuti (2018), which concluded that the quality of BelDReciably products is positive and partially significant to consumer satisfaction. This indicates that the higher the quality of the product, the higher the level of customer satisfaction. Resto SOLARIA Mall Lippo Cikarang should be able to improve the quality of its products. This can be done by creating something new such as a more varied beverage menu so that consumers have many choices and avoid consumers saturated with existing menus. By creating quality products, business continuity is guaranteed. Quality products can help Resto SOLARIA Mall Lippo Cikarang attract new consumers and create customer satisfaction so that it will retain consumers who have visited the Resto SOLARIA Mall Lippo Cikarang several times. Thus, the quality of belDReciably products to customer satisfaction, if the product quality of Resto SOLARIA Mall Lippo Cikarang is improved then the customer satisfaction of Resto SOLARIA Mall Lippo Cikarang will increase.

\section{Influence of Price on Consumer Satisfaction at Resto SOLARIA Mall Lippo Cikarang}

This research proves that the second hypothesis is accepted, that the price of BelDReciably positive and significant to the satisfaction of consumers who have visited and visited the Resto SOLARIA Mall Lippo Cikarang. Based on the results of the partial hypothesis test the influence of price on consumer satisfaction obtained a regression coefficient value of 1,011 . At the rate of significance of $5 \%$, t count is 7,818 greater than the table t value of 1,984 . The resulting significance value of 0.000 means

Erdi,Dadang Heri Kusumah, Sumardjono, and Dimas Ari Darmantyo. Influence of product quality, price, and quality of service to customer satisfaction (study on Resto Solaria Mall Lippo Cikarang) 
less than 0.05. Therefore, it can be said that the variable price of BelDReciably is significant to consumer satisfaction. Because the coefficient of regression value is positive, it can be concluded that the variable price of BelDReciably positive is significant to the customer satisfaction of Resto SOLARIA Mall Lippo Cikarang, so the second hypothesis is accepted. At a certain price level, if the benefits felt by consumers Resto SOLARIA Mall Lippo Cikarang increases, then the value will increase. Thus, if the value felt by consumers Resto SOLARIA Mall Lippo Cikarang is higher, it will create customer satisfaction.

The results of this study are in line with research conducted by Gladis Mongkau, Lotje Kawet, and Jantje Sepang conducted a research with the title "The Influence of Product Quality, Price, and Place On Consumer Satisfaction in Remboken Traditional Market"(Case Study on Sinuian Village Kec. .Remboken Community) which has been published in the journal EMBA, Sam Ratulangi University (2017). The conclusion obtained is that price has a significant influence on the satisfaction of consumers of Remboken Traditional Market. Thus, the results of this research support the results of previous research.

\section{Influence of Quality of Service on Consumer Satisfaction at Resto SOLARIA Mall Lippo Cikarang}

This research proves that the third hypothesis received is the quality of service BelDReciably positive and significant to the satisfaction of old and old customers who have visited SOLARIA Mall Lippo Cikarang. Based on the results of partial calculation of the effect of service quality on customer satisfaction obtained a regression coefficient value of 0.678 . At the rate of significance of $5 \%, t$ count is 8,882 greater than the table $t$ value of 1,984 . The resulting significance value of 0.000 means less than 0.05 . Therefore, it can be said that the variable quality of service BelDReciably significant to customer satisfaction. Because the coefficient of regression value is positive, it can be concluded that the variable quality of service BelDReciably positive and significant to customer satisfaction Resto SOLARIA Mall Lippo Cikarang, so the third hypothesis is accepted. The higher or better the quality of service at Resto SOLARIA Mall Lippo Cikarang, the customer satisfaction of Resto SOLARIA Mall Lippo Cikarang will increase.

The results of this research are in line with research conducted by Muhammad Reza Pahlawan, et al (2019) with an article entitled "Influence of Product Quality \& Service Quality on Improving Customer Satisfaction and Loyalty of Makassar Water District Company". The conclusion obtained is the quality of service BelDReciably positive to improve customer satisfaction of the Regional Water Company of Makasssar City. Thus, the results of this study support the results of previous research.

4. Influence of Product Quality, Price and Quality of Service on Consumer Satisfaction at Resto SOLARIA Mall Lippo Cikarang.

Based on the results of simultaneous calculations of the influence of product quality, price, and service quality on customer satisfaction obtained a significance value of 0.000 which means less than 0.05 . At the level of significance $5 \%$ obtained $F$ count of 38,012 greater than the value of $F$ table of 2.70 . Therefore, from these results can be said that the variable quality of products, prices, and quality of service BelDReciably significantly to the satisfaction of consumers Resto SOLARIA Mall Lippo Cikarang. Because the value of $F_{\text {count }}$ has a positive value, it can be concluded that the variable product quality, price, and quality of service simultaneously or together BelDReciably positive and significant to customer satisfaction Resto SOLARIA Mall Lippo Cikarang, so the fourth hypothesis is accepted.

\section{Conclusion}

\section{CONCLUSIONS AND RECOMMENDATIONS}

Erdi,Dadang Heri Kusumah, Sumardjono, and Dimas Ari Darmantyo. Influence of product quality, price, and quality of service to customer satisfaction (study on Resto Solaria Mall Lippo

Cikarang) 
1. There is a positive and significant effect of product quality on consumer satisfaction at Resto SOLARIA Mall Lippo Cikarang. This can be shown by a regression coefficient of 0.597 . At the $5 \%$ significance level, the t-count is 9.430 , which is greater than the t-table value of 1.984 . As for the resulting significance value of 0.000 which means less than 0.05 . So it can be concluded that the product quality variable BelDReciably significantly on consumer satisfaction. Because the regression coefficient value has a positive value, it can be concluded that the product quality variable BelDReciably positive and significant on consumer satisfaction at Resto SOLARIA Mall Lippo Cikarang, so the first hypothesis is accepted.

2. The price of BelDReciably positive and significant on consumer satisfaction at Resto SOLARIA Mall Lippo Cikarang. This can be shown by the regression coefficient value of 1.011 . At the $5 \%$ significance level, the t-count is 7.818 , which is greater than the t-table value of 1.984 . The resulting significance value of 0.000 means less than 0.05 . Therefore, it can be concluded that the price variable BelDReciably significant to consumer satisfaction. Because the regression coefficient is positive, it can be concluded that the price variable BelDReciably has a significant positive effect on customer satisfaction at Resto SOLARIA Mall Lippo Cikarang, so the second hypothesis is accepted. At a certain price level, if the benefits perceived by consumers increase, the value will increase.

3. The quality of service of Resto SOLARIA Mall Lippo Cikarang BeIDReciably positive and significant to customer satisfaction. This is indicated by the regression coefficient value of 0.678 . At the $5 \%$ significance level, the t-count is 8.882 , which is greater than the t-table value of 1.984 . The resulting significance value of 0.000 means less than 0.05 . Therefore, it can be said that the service quality variable is BelDReciably significant to customer satisfaction. Because the regression coefficient is positive, it can be concluded that the service quality variable BeIDReciably significantly positive on customer satisfaction at Resto SOLARIA Mall Lippo Cikarang, so we accept Hypothesis 3. The higher or better the service quality of Resto SOLARIA Mall Lippo Cikarang.

4.Based on the results of the simultaneous calculation of the effect of product quality, price, and service quality on customer satisfaction, a significance value of 0.000 is obtained, which means it is smaller than 0.05 . At the $5 \%$ significance level, the calculated $F$ is 38,012 , which is greater than the $F$ table value of 2.70. So from these results it can be said that the variables of product quality, price, and service quality BelDReciably significantly on consumer satisfaction at Resto SOLARIA Mall Lippo Cikarang. Because the value of Fcount has a positive value, it can be concluded that the variables of product quality, price, and service quality simultaneously or together BelDReciably positive and significant on consumer satisfaction at Resto SOLARIA Mall Lippo Cikarang, so the fourth hypothesis is accepted.

\section{Recommendations}

\section{For Resto SOLARIA Mall Lippo Cikarang}

Resto SOLARIA Mall Lippo Cikarang must be able to improve the quality of its products. This can be done by creating something new, such as a more varied drink menu so that consumers have many choices and avoid consumers being bored with the existing menu. By creating quality products, business continuity is guaranteed.

The price set by the Resto SOLARIA Mall Lippo Cikarang must also be adjusted to the quality of the product or service offered to consumers. This

Erdi,Dadang Heri Kusumah, Sumardjono, and Dimas Ari Darmantyo. Influence of product quality, price, and quality of service to customer satisfaction (study on Resto Solaria Mall Lippo Cikarang) 
makes consumers who are visiting the Resto SOLARIA Mall Lippo Cikarang feel satisfied.

Resto SOLARIA Mall Lippo Cikarang should be able to increase speed, responsiveness of waiters to be more reliable and responsive in serving consumers, when consumers finish ordering the waiter should immediately clean the dirty tableware on the table. This makes consumers who are visiting the Resto SOLARIA Mall Lippo Cikarang feel satisfied.

\section{For Other Reserchers}

Based on the results of the research, it shows that the results of this research support the existing theory. In addition, further researchers should also add other variables that have not been listed in this research because there are still other factors that can affect consumer satisfaction, such as location, promotions, store atmosphere, and others so that various statistical models can be better obtained.

\section{REFERENCES}

Afnina \& Yulia Hastuti (2018). Pengaruh Kualitas Produk Terhadap Kepuasan Pelanggan Studi Kasus Pada Toko Aneka Jaya Furniture di Langsa. Jurnal Samudera Ekonomi dan Bisnis. 9 (1),

Kotler, P., \& K.L Keller. (2013). Manajemen Pemasaran Jilid 1. Cetakan Ketigabelas. Jakarta; Erlangga.

Kotler, P., \& K.L Keller. (2013). Manajemen Pemasaran Jilid 2. Cetakan Ketiga belas. Jakarta; Erlangga.

Lovelock, C., J. Wirtz, \& J. Mussry. (2010). Pemasaran Jasa Jilid II. Jakarta: Erlangga.

Mongkau, Gladis. \{et.al\}. (2017) Pengaruh Kualitas Produk, Harga,dan Tempat Terhadap Kepuasan Konsumen Pada Pasar Tradisional Remboken: Studi Kasus Pada Masyarakat Desa Sinuian Kec. Remboken. Jurnal EMBA, Universitas Sam Ratulangi. 5 (2).

Nel,Arianty. (2015) Pengaruh Kualitas Pelayanan dan Kualitas Produk Terhadap Kepuasan Konsumen Handphone Samsung. Jurnal IImiah Manajemen dan Bisnis, 16 (2).

Pahlawan, M.R. (2019) Pengaruh Kualitas Produk dan Kualitas Pelayanan Terhadap Peningkatan Kepuasan dan Loyalitas Pelanggan Perusahaan Daerah Air Minum Kota Makasssar. Journal of Business Adminitration. 3 (2),

Stanton. J. Wiliam. (2018). Prinsip Pemasaran. Jilid 1\& 2. Jakarta: Erlangga.

Sugiyono. (2018). Metode Penelitian Kuantitatif. Bandung: Alfabeta.

Sumardjono,S. \& Ardila, H.(2018) The Effect of Marketing Mix upon The Consumer's Decision Making to Buy a Product at PT. Griya Pagelaran Bogor. The Management Journal of Binaniaga,3(1), 59-70. doi: 10.33062/mjb.v3i1.241

Tjiptono, F. (2014). Pemasaran Jasa. Malang: Banyumedia Publishing.

Tjiptono, F. (2019). Strategi Pemasaran. Yogyakarta: Andi.

Erdi,Dadang Heri Kusumah, Sumardjono, and Dimas Ari Darmantyo. Influence of product quality, price, and quality of service to customer satisfaction (study on Resto Solaria Mall Lippo

Cikarang) 